\begin{tabular}{|c|c|c|c|c|c|c|}
\hline \multirow{4}{*}{ Impact Factor: } & ISRA (India) & $=3.117$ & SIS (USA) & $=0.912$ & ICV (Poland) & $=6.630$ \\
\hline & ISI (Dubai, UAF & $=0.829$ & РИНЦ (Russia) & $=0.156$ & PIF (India) & $=1.940$ \\
\hline & GIF (Australia) & $=0.564$ & ESJI (KZ) & $=5.015$ & IBI (India) & $=4.260$ \\
\hline & JIF & $=1500$ & & & & \\
\hline
\end{tabular}

\begin{tabular}{|c|c|}
\hline $\begin{array}{l}\text { SOI: } \underline{1.1 / 7} \\
\text { International } \\
\text { Theoretical } \mathbf{\&}\end{array}$ & $\begin{array}{l}\mathrm{AS} \\
\text { ientific Journal }\end{array}$ \\
\hline p-ISSN: 2308-4944 (print) & e-ISSN: 2409-0085 (online) \\
\hline Year: 2018 & Volume: 68 \\
\hline Published: 30.12 .2018 & tttp://T-Science.org \\
\hline
\end{tabular}

SECTION 31.Economic research, finance, innovation, risk management.
QR - Issue
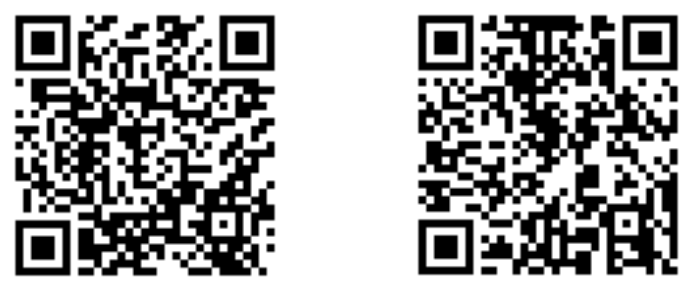

Shakhnoza Xamidovna Rakhmatullaeva senior teacher,

"Labour economy and sociology" department, Tashkent state university of economics, Tashkent city, Republic of Uzbekistan

\title{
FOREIGN EXPERIENCE IN LABOR PRODUCTIVITY MANAGEMENT
}

Abstract: The article discusses the international experience of labor productivity management: the United States and Japan. The management models are described in detail as mechanical, system and models oriented to human resources. Examined in the world of methods and approaches to improving labor productivity in industrial enterprises.

Key words: labor productivity, management methods, management, personnel, motivation, control.

Language: English

Citation: Rakhmatullaeva, S. X. (2018). Foreign experience in labor productivity management. ISJ Theoretical \& Applied Science, 12 (68), 360-364.

Soi: http://s-o-i.org/1.1/TAS-12-68-54 Doi: crossef https://dx.doi.org/10.15863/TAS.2018.12.68.54

\section{Introduction}

In modern conditions of development of a market economy, one of the main problems of the practice of managing enterprises is the process of managing labor productivity. At enterprises, very little attention is paid to the indicator of labor productivity. As a rule, no one is engaged in its analysis, control, planning, forecasting. This is explained either by an elementary misunderstanding of the importance, the priority of the problem, or by the unwillingness to understand this importance, or by the unwillingness to waste time and money on solving it. However, the experience of the industrially developed countries of the world, the leading corporations in them suggests that they do not spare either time or money for finding and implementing reserves of productivity growth, and later it turns into a decrease in production and nonproduction costs, growth in profits, and success in competition. on the world market. Back in the last century, labor productivity attracted much attention of foreign academic economists and organizers, such as G. Emerson, for example. He first raised the issue of production efficiency on a large scale. In his book "The Twelve Principles of Productivity," he formulated the principles of proper organization of both the labor of an individual contractor and the production process of an enterprise (tab. 1). The main idea of Emerson is as follows: true labor productivity always gives maximum results with minimum effort. G. Emerson believes that production should not be adjusted to the management, but management should serve the production [4].

\section{Literature review}

The degree of elaboration of the problem. Foreign economics classics made a significant contribution to the development of the theory of labor: William Petty, A. Smith, D. Ricardo, G.Ch. Carey, J.S. Mill, F. Taylor, G. Emerson.

The importance of labor productivity to ensure the sustainability of the development of the national economy was considered in the works of researchers E.G. Antosenkova, R.V. Baburova, I.S. Vinnikova, A.K. Gasteva, B.M. Genkina, Su. Gorbarets, Yu.P. Kokina, V.V. Kulikova, V.I. Lenin, N.A. Morozova, A.A. Nikiforov, PF Petrochenko, M.Yu. Pitkevich, E.A. Polov-kina, OG Semenyuta, D.P. Smolkova, S.G. Strumilina, A.I. Scherbakova, R.A. Yakovlev. At the same time, most of the listed authors took for an axiom the statement that the growth of wages should not exceed the growth of labor productivity.

Analysis and results

Studies show that labor productivity is a dynamic indicator, its increase is the most important condition for the growth of material production and income. 


\begin{tabular}{|c|c|c|c|c|c|c|}
\hline \multirow{4}{*}{ Impact Factor: } & ISRA (India) & $=3.117$ & SIS (USA) & $=0.912$ & ICV (Poland) & $=6.630$ \\
\hline & ISI (Dubai, UAI & $=0.829$ & РИНЦ (Russia) & $=0.156$ & PIF (India) & $=1.940$ \\
\hline & GIF (Australia) & $=0.564$ & ESJI (KZ) & $=5.015$ & IBI (India) & $=4.260$ \\
\hline & JIF & $=1.500$ & SJIF (Morocco) & $=5.667$ & & \\
\hline
\end{tabular}

Labor productivity of an individual worker depends on his abilities, skills and knowledge, age, health status and other reasons.

From the position of effective work for the employer, it is important to find an employee whose working capacity and productivity is potentially above average.

A special role is played by factors affecting the relationship in the team and labor discipline, the value system of employees, the principles of interaction affecting the target attitudes of staff and the behavior of employees, their interaction both in groups and in the team as a whole. Not unimportant role have organizational factors, covering a whole range of actions for the organization of labor and personnel management, including the choice of size, specialization and combination, as a form of organization of production at the enterprise, style of enterprise management, definition of the tasks of its division. [5]

The foreign experience of the effectiveness of the incentive effect of wages on workers entirely depends on the reasonableness of the proportions in wages.

The peculiarity of labor stimulation is the intrafirm differentiation of wages, which has two
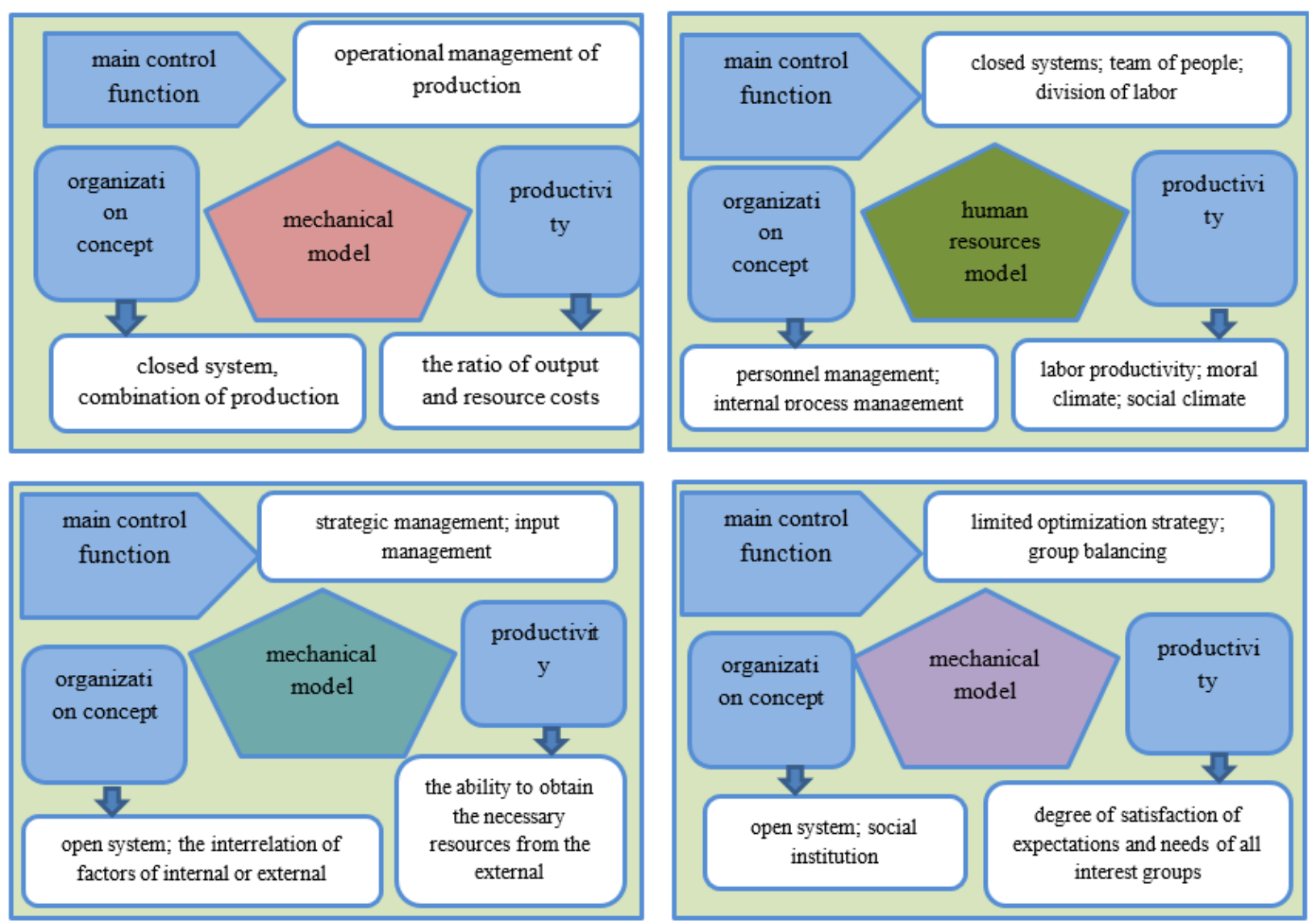

sections. One of them reflects the indirect differences differentiation of wages, the subsequent goal of which is to link tariff rates or salaries with the amount of labor. What ensures the interest of workers in improving the level of professional knowledge and the accumulation of practical experience.

Foreign experience suggests that the industrialized countries of the world are constantly discovering reserves of growth of labor productivity, which in the future will reduce production costs, increase the competitiveness of enterprises in the world market, increase profits [1].

In classical theory, the emergence of enterprises of various types was accompanied by well-known theories in management. Enterprise models of the 20th century The mechanical model was formed at the end of the 19th century and became widespread in the first half of the 20th century (see Fig. 1 below). From the standpoint of this model, an enterprise is considered as a mechanism, which is a combination of many factors: the means of production, labor, raw materials and materials. between simple and complex labor. This is a vertical

Fig.1. Models of labour effectiveness and management. 


\begin{tabular}{|c|c|c|c|c|c|c|}
\hline \multirow{4}{*}{ Impact Factor: } & ISRA (India) & $=3.117$ & SIS (USA) & $=0.912$ & ICV (Poland) & $=6.630$ \\
\hline & ISI (Dubai, UAI & $=0.829$ & РИНЦ (Russia) & $=0.156$ & PIF (India) & $=1.940$ \\
\hline & GIF (Australia) & $=0.564$ & ESJI (KZ) & $=5.015$ & IBI (India) & $=4.260$ \\
\hline & JIF & $=1.500$ & SJIF (Morocco) & $=5.667$ & & \\
\hline
\end{tabular}

Therefore, in the analysis process, great importance is attached to the technical and economic analysis and the influence of various factors on productivity. The main trend of increasing productivity is cost reduction. We note that the mechanical model of an enterprise is critically evaluated by modern science and practice because of its desire to preserve stability (conservatism), universal control over the quality and implementation of planned tasks, ideas about top managers who are "wiser than market". The model focused on human resources is a group of people using the principles of division and cooperation of labor. The systems of scientific management of labor collectives working in socialist enterprises belonged to this type. Special attention was paid to the management style, its influence on the increase in labor productivity and employee satisfaction with their work, their involvement in the process of developing management decisions (see Fig. 2 above). The system model is presented in the form of a complex hierarchical system that is in close contact with the external environment (see Fig. 3 above). The main idea is to recognize all elements of the system and the system as a whole with the external environment. It should be noted that the effectiveness of this model is doubtful, due to the fact that it was formed under the supervision of the state and the effectiveness was determined mainly by the internal environment of the organization. The model of an organization as a public education is presented in the form of an integrated system, in accordance with which organizations should take into account the interests of consumers, suppliers, competitors, and society as a whole (see Fig. 4 above). The result of such a system is the complete satisfaction of the expectations and needs of all interest groups. In modern realities, organizations do not use only one management model, but move from one to another or have elements of all four basic concepts depending on the combination of external and internal factors. [10]

Note that the increase in labor productivity has occurred, mainly due to the capacity utilization and an increase in the number of the working population. However, a further increase in the productivity indicator due to the same factors is impossible, and an integrated approach to solving problems is necessary. The models of labor productivity management in the USA and Japan are radically different (Table 1).

Table-1. Methods and approaches to increasing productivity in industrial enterprises

\begin{tabular}{|c|c|c|c|}
\hline & 1960-1970 yу & 1980-1990 уу & $2000-2010$ yy \\
\hline USA & $\begin{array}{l}\text { - Production Management } \\
\text { Orientation } \\
\text { - Cost Minimization - } \\
\text { Mechanization of Production } \\
\text { Processes } \\
\text { - Increased Labor and Capital }\end{array}$ & $\begin{array}{l}\text { - Reducing the complexity of } \\
\text { technological equipment in the } \\
\text { manufacture of high-tech and } \\
\text { complex products } \\
\text { - A new leap in increasing } \\
\text { productivity } \\
\text { - The creation of a humane } \\
\text { society - Investment in } \\
\text { innovation }\end{array}$ & $\begin{array}{l}\text { - Reducing hierarchical levels of } \\
\text { management - Improving quality } \\
\text { while minimizing production } \\
\text { costs - Using the latest } \\
\text { technologies in innovation - } \\
\text { Human resource management }\end{array}$ \\
\hline Japan & $\begin{array}{l}\text { - Cost reduction } \\
\text { - Productivity Improvement } \\
\text { Program } \\
\text { - Internship in the USA, study of } \\
\text { management methods - } \\
\text { Participation in the development } \\
\text { of measures to increase the } \\
\text { productivity of administration } \\
\text { and labor collective } \\
\text { - Use of electronics and computer } \\
\text { technology }\end{array}$ & $\begin{array}{l}\text { - High-quality products at } \\
\text { minimum cost } \\
\text { - Preserving the principles of } \\
\text { productivity growth, as the basis } \\
\text { for economic growth - } \\
\text { Developing your own model of } \\
\text { "human potential" } \\
\text { - Humane relations between the } \\
\text { administration and the employee } \\
\text { - Growth of funding in } \\
\text { innovation }\end{array}$ & $\begin{array}{l}\text { - Reducing the complexity of } \\
\text { technological equipment in the } \\
\text { manufacture of high-tech and } \\
\text { complex products } \\
\text { - A new leap in increasing } \\
\text { productivity } \\
\text { - The system of decision-making } \\
\text { "Ringisei" } \\
\text { - The creation of a humane } \\
\text { society - Investment in } \\
\text { innovation }\end{array}$ \\
\hline
\end{tabular}

Source: collected by the author.

The peculiarity of the Japanese model of management is its focus on human resources. It is the Japanese model of management that ensures the harmonic relationship between production, sales and the flow of finance. The Japanese management model boils down to optimizing work methods: identifying and analyzing problems, creating new work methods (instructions), adapting working 


\begin{tabular}{|c|c|c|c|c|c|c|}
\hline \multirow{4}{*}{ Impact Factor: } & ISRA (India) & $=3.117$ & SIS (USA) & $=0.912$ & ICV (Poland) & $=6.630$ \\
\hline & ISI (Dubai, UAE & $=0.829$ & РИНЦ (Russia) & $=0.156$ & PIF (India) & $=1.940$ \\
\hline & GIF (Australia) & $=0.564$ & ESJI (KZ) & $=\mathbf{5 . 0 1 5}$ & IBI (India) & $=4.260$ \\
\hline & JIF & $=1.500$ & SJIF (Morocco) & $=5.667$ & & \\
\hline
\end{tabular}

conditions and standards, depending on the work of the staff. The system of labor incentives in the Japanese model is developed at a high level: public recognition of merit, social programs, etc. We also note that thrift and economy are characteristic of Japanese culture, which is inextricably linked with the creation of high-quality products. This is reflected in technologies such as Lean-approach, Kaizen system (continuous improvement), Kanban (continuous replenishment of stocks), Pok-yoke (error protection) and many others. [6].

\section{Conclusion}

Marked a vivid example of the superiority of the Japanese model of control over the American. The Japanese company Matsushita, which bought the TV manufacturing company of the American firm Motorola TV, was able to reduce the warranty repair fund from $\$ 22$ million to $\$ 3.5$ million, also reduce the number of manufacturing defects by 100 receivers from 140 to 6 , reduce complaints in the first 90 days after the sale from 70 to $7 \%$ and reduce staff turnover from 30 to $1 \%$ per year [7]. One of the main reasons for the difficulty of implementing lean transformations lies in the specific management culture of the Japanese. Respectful attitude to the regulations there and the highest performing discipline are combined in Japanese companies with the tradition of consensus - joint discussion of decisions. The coherence of actions, teamwork are of great importance for the Japanese worker. Labor Productivity Management in the USA Let us examine the experience of labor productivity management in the USA. In contrast to the Japanese approach associated with continuous and integrated optimization of working methods, the American tradition is characterized by an inverse sequence: first, the maximum attainable goal or result is defined in terms of productivity and quality, and then measures are taken to achieve this result. It is based on a measurement and benchmarking system. One of the most common measurement indicators is OEE (overall equipment effectiveness), which is how efficient the main production assets are used. This indicator consists of three components: availability, productivity and quality. [8]

After setting goals, identify the causes of problems and plan changes. The reasons may be: improper placement of equipment, excessive or, on the contrary, insufficient capacity at one of the stages of production, incorrect sequence of operations, suboptimal number or distribution of duties, etc. Not every manager has enough knowledge and experience, and sometimes even time to take all the necessary measurements. [9] It is in the American tradition that there are often dedicated quality services or divisions of labor rationing, while in many Japanese enterprises these functions are performed by employees of the main production units. Thus, the idea of the Japanese approach: creating a culture of continuous improvement, supplying workers with the necessary methods, counting on a responsible, team approach to change and submission to the rules adopted in the team. While the American approach is designed for a different, managerial culture: much more personal, depending on the decisions of specific people [6].

\section{References:}

1. Pritulin, S. V. (2011). Fundamentals of labor productivity management in organizations. Young scientist, № 3, T. 1 .

2. (n.d.). Will the productivity of Russian workers be as high as abroad? [Electronic resource]. the Japanese company Matsushita, which bought the TV manufacturing enterprise of the American firm Motorola TV, was able to ... reduce staff turnover from $30 \%$ to $1 \%$ per year labor economics.

3. (n.d.). Why labor productivity in Russia is lower than abroad? Retrieved 2018, from http://myvolga.ru/content/pochemuproizvoditelnosttruda-v-rossii-nizhechem-zarubezhom
4. Hooters, A. (2010). Comparison of labor productivity in Russia and America. Retrieved 2018, from http://www.uppro.com/library/production_management/produ ctivity/sravnenye-pokaz.html

5. Golovanov, A. I. (2011). Labor productivity as a foundation for the growth of the Russian economy. Tomsk State University Bulletin, № 4 (16).

6. Bezruchko, P. (2011). Increasing Labor Productivity: International Experience and Russian Specifics. Retrieved 2018, from http://www.uppro.ru/library/production management/producti vity/rossijskaja-specifika.html 


\begin{tabular}{|c|c|c|c|c|c|c|}
\hline \multirow{4}{*}{ Impact Factor: } & ISRA (India) & $=3.117$ & SIS (USA) & $=0.912$ & ICV (Poland) & $=6.630$ \\
\hline & ISI (Dubai, UAE & $=0.829$ & РИНЦ (Russia) & $=0.156$ & PIF (India) & $=1.940$ \\
\hline & GIF (Australia) & $=0.564$ & ESJI (KZ) & $=\mathbf{5 . 0 1 5}$ & IBI (India) & $=4.260$ \\
\hline & JIF & $=1.500$ & SJIF (Morocco) & $=5.667$ & & \\
\hline
\end{tabular}

7. Knorring, V. I. (2007). Theory, practice and art of management. Textbook for universities in the specialty "Fundamentals of Management." - 3rd ed., Rev. and add. (p.544). M.: NORMA.

8. Andreein, N. (2010). Kontsenka is a model for managing the creation and development of competitive machine-building enterprises. Russian Journal of Entrepreneurship, № 7 (2), 106-111.
9. Abrosimova, O. S., Yeleneva, Y. Y., \& Zamlelaya, A. T. (2010). Development of a methodology for the classification of investment projects in the framework of creating a system of strategic management of investment costs. Russian Entrepreneurship, № $8(2)$, 53-57. www.inventech.ru

10. Matskulyak, I. (2009). Labor productivity: essence, forms of manifestation, level. Business Economics, № 11, 27-31. 